\title{
THE MIGRATION POLICY OF IRAN AND TURKEY FROM PAST \\ TO PRESENT AND MIGRATION GOVERNANCE IN THE \\ CONTEXT OF MIGRANTS
}

\author{
Kerim KARADAL, PhD. C. (i) 1* \\ Mortaza CHAYCHI SEMSARI, PhD. C (iD) 2 \\ Ŏguz KESKIN (iD 3 \\ 1 Uludağ University, Institute of Social Sciences, Management and Organization, kerimkaradal@ gmail.com *Correspondent Author. \\ 2 Istanbul University, Political Science and Public Administration, alimortezacaycisemsari@gmail.com \\ 3 Haci Bayram Veli University, Political Science and Public Administration, aliyar43@yahoo.com
}

\section{Article history:}

Submission 19 November 2020

Revision 10 December 2020

Accepted 25 January 2021

Available online 31 August 2021

\section{Keywords:}

Migration,

Migration Management,

Migration Governance,

Iran,

Turkey.

DOI:

https://doi.org/10.32936/pssi.v5i2.258

\begin{abstract}
A b s t r a c t
The phenomenon of migration has been one of the important factors affecting and shaping the lives of countries and societies throughout history. In this respect, the evolution of immigration in its historical process has become a policy that is more carefully followed by countries today. So much so that the phenomenon of immigration has ceased to be based simply on economy around the world and has become a threat to the security of countries with the change of migration trends.

In every period of its history, Iran and Turkey have been a country of immigration for various reasons. Migration management and humanitarian fields are discussed in the article. In recent years, the issue of migration has been increasingly on the international agenda and is now seen as a very important issue for all governments; In terms of Iran, immigration management has become an issue that needs to be dealt with comprehensively and systematically in recent years for immigrants from countries such as Iraq, Afghanistan and Pakistan, and for Turkey, those coming from Syria, Afghanistan and Iraq. As a result of the intensification of migration movements in the world, the two countries have become more sensitive to the issue of migration in order to improve their migration management and make the necessary arrangements. In this study, migration management, migration governance, migration and development, regulation of migration, social integration approaches and models of immigrants are examined under two separate headings. The relationship between the mother country Iran and Turkey, immigration and identity policies in this area will be read and the consequences of this process on the immigration policies of these countries and its impact on countries will be examined and analyzed.
\end{abstract}

\section{Introduction}

The phenomenon of migration has become one of the important factors affecting the life of societies and states over time and especially in recent times. Therefore, the evolution of migration should be well known. The phenomenon of migration, which has become affecting the security of states with its rapid increase in addition to its economic basis, also leads states to cooperation with the power of internationalization. Therefore, it is useful to see migration as a tool that affects the order of states rather than displacement.
The fact that migration is a multidimensional and complex phenomenon on its own brings up migration management. As well as the internationalization of migration, it requires good implementation of migration management (management) by the states. Otherwise, the negative effects of mass migrations carry the risk of causing disruptions in the internal functioning of states and social turmoil. The aim of this study is to focus on the migration management(s) of Turkey and Iran, two neighboring countries that have ties with the transformation of migration into an international form. In the first part, information about the 
conceptual framework of migration will be given. Then, in the last part, which will focus on the internal and external migration of Turkey and Iran, the migration management(s) of the two countries will be mentioned.

\section{The Conceptual Framework of Migration}

The phenomenon of migration manifests itself in different definition ranges. The temporal evolution of these intervals includes a politicized integration from economic conditioning to citizenship bond. While this disclosure about the phenomenon of migration does not have any effect on the economic level for the immigrating states at the beginning, it is possible for the immigrants to integrate into the countries they go to, to form a super-ego etc. Points to the necessity of legal changes. In this respect, the evolution of the phenomenon in a full understanding actually leaves countries in a dilemma about which aspect (political, social, physical, religious, cultural, economic and security) they should approach the phenomenon of migration. "Guest worker programs" to the phenomenon of migration, which was seen economically in the 1950s (Yükseker, 2018) is known to be based on. On the other hand, the mass influx of people coming from colonial countries to the West, after a while, combined with the cultures of the immigrants of the Western countries (Just as Algerian music is accepted in France and Rock music is accepted in the world) caused them to meet. Castles and Miller collect the general migration trends in the world under four headings (2008: 12): First, on the globalization of migration. Countries are affected by immigration problems with different social, economic and political backgrounds. The second is the acceleration of migration. International migration movements are increasing in the world. This increase is affected by government policies. The third is the differentiation of migration. Labor migration, migration towards refugees or permanent settlements diversify migrations.

Therefore, it creates an obstacle for political mechanisms in the national and international arena. Finally, there is the feminization of migration. An important part of the immigrants, especially since the $60 \mathrm{~s}$, is women's mobility in the field of labor, and this situation is increasing with the effect of globalization. Those who argue that the internationalization of migration has become a complex and set of problems (Miller and Castles, 2008; Göksel, 2019) There are also those who think that it should be viewed from a positive perspective (Akhtar, 2018). According to those who see it as a problem, they argue that the internationalization of migration will cause a different hybridization in the social codes and cultural structures of the countries, and therefore countries will have political difficulties in overcoming this. As a matter of fact, Chambers (2014) argues that the masses flowing from underdeveloped countries to developed countries create "occupation areas" in many places from the entertainment concept to the cities of the countries they come from. In this respect, the problem of international migration becomes a situation that requires attention in all political areas of the countries, and it highlights the issue of decision-making mechanisms to take more effective measures on the problem of migration. Among these problems, it is seen that more importance is given to security today. Turkey's exposure to mass migrations since 2011 and Iran's large border geography have caused these two countries to become more sensitive to border security and internal security issues. According to Haj Hosseini (2006), the fact that migration has become a security problem affects the fragmentation of national unity. On the other hand, due to political instability and successive political tensions, the lack of a comprehensive governance umbrella, the migration problem takes an international form for countries (Akhbari and Mohammad, 2009). The fact that immigration has become an international national problem shows its effect mostly on nation states. In this direction, today, nation-states are changing their policies in order to eliminate or reduce the threat of migration.

On the one hand, globalization and European integration, on the other hand, the decentralization phenomenon pushes nation-states to take legal measures on migration (Özer and Keskin, 2019). As a matter of fact, Akhtar emphasizes that some variables are effective against the immigrants in the receiving states. These; The nature of the existing community, the period and way of migration, historical ties, the size of cultural differences and the physical characteristics of the immigrant (2018: 20-1). In this context, migration emerges as a type of multiculturalism (Eagleton, 2011: 78). This feature of migration creates a compelling situation on nation states such as Turkey and Iran not only in cultural and social terms but also in education and politics. The occurrence of cultural and social problems for those fleeing the Syrian war and coming to Turkey and the creation of their own living spaces in Turkey are important in that they represent a typical example of this. On the other hand, Lahsaeizadeh (1989) argues that not only different cultural norms and values of migration are introduced from outside, but also the adaptation process begins when immigrants encounter different social environments, and this is significant in terms of integration. The national and internationalization of migration also enables new integration models, subcultures or different forms of imposition (sexual policies, artistic combinations, strategic migration policies) with the citizens of the destination country and countries. Therefore, it is seen that a "political positivism" is needed for countries, since the evolution of the phenomenon is better analyzed and supported by local policies, without placing the phenomenon of migration in a simple framework -limited definitions at the legal level. Governments and states are heading 
towards difficulty in controlling the growing wave of immigration in a globalized time. The mixing of blood ties, the use of immigration as a political power, the fluidity of the global economy and the migration movements that come with it cause cracks in the ethnic structures of the countries and cause problems in security issues.

\section{Domestic and External Migration in Iran and Turkey}

The gap created by globalization and decentralization due to decentralization has many positive developments for countries such as achieving a better life, emphasizing individual rights, improvements in health systems, expansion of freedom of travel, increase in population, spatial growth of socialization, as well as the displacement of the increasing population, labor migration due to capital mobility, volatility in taxes, illegal immigration movements, uncertainties in the situation of immigrants who have become settled in the political arena, the construction of new hybrid cultures that have moved from the economic to the political, from the ethnic field to the social sphere, and the challenges that must be confronted, especially for nation states. brings with it. In this respect, the fact that immigration is internal and external has made it necessary for countries to produce policies to reduce tensions in legislation and social areas.

Iran's integration into the global capitalist system, especially the eco-politics of oil and rural-urban migration has further increased its importance. In this context, the country has been experiencing difficulties in directing internal migration since the 1960s. Some of these challenges include improving the situation of immigration-receiving cities, reducing tensions between social movements and ethnic identities, and the recognition of those who are starting to settle in oil and commercial areas and trying to find low-paid jobs with residents. The period between 1966 and 1986 is considered as the change in Iran's economic and social structure and the beginning of rapid urban migration. On the other hand, due to the increase in the population and the number of cities, there has been a significant increase in migration from city to city and it has become dominant in favor of immigrants. While the migration to the cities, which increased significantly between this period, tended to be between cities, it turned to intraprovincial migration in the short term (Ershad and Mina, 2010; Mahmoudi and Abdullah 2004). Over the past few decades in Iranian history, the fundamental transformation of the social structure and productive forces has formed the basis of migration. In a short period of time, the trend of social life of several thousand years has undergone serious changes and dramatic changes. These developments have caused significant differences for Iran with its unique historical past and new eco-politics. For example, the growth and expansion of capitalist relations coincided with the increasing role of oil in Iran's political economy. The adoption of new laws along with the modernization process strengthened the basic basis of migration. This was followed by the introduction of a compulsory military service system, forcing their children to study in primary schools, and the establishment of new government offices and institutions. As a result of the fall of Reza Shah, the migration of some of the rural population to the cities accelerated. Meanwhile, the centralized planning process in the country helped transform cities into points of attraction and population concentration (Aslani, 2006; Afrough, 1998).

After the 1979 Islamic Revolution, the economic, social and political development process focusing on cities, especially big cities, continues to be an influential factor for migration. In this period, the number of provinces with negative rural population growth rate increased from 11 provinces in 1991 to 25 in 2011, indicating that this inequality exists not only in rural areas but also in wider geographical areas. Over the last few decades, the proportion of the country's rural population has declined, with the country's urban population rising from $31.4 \%$ in 1956 to $71.3 \%$ in 2012, followed by a decline in the country's rural population from $68.6 \%$ in 1956 to 2012. It contributed to the decrease to 28.7\% (Bozan, 2017; Iman, 1999; İrmelo, 1984).

The Islamic Republic of Iran, more than any other country in the region, is faced with the phenomenon of immigrants on a large and continuous basis. In order to cope with this phenomenon, the system puts serious emphasis on border security with the development of the country's border. Due to the oil fields in the region, Iran receives serious migration from neighboring countries in terms of manpower. Illegal immigrants (Afghan and Iraqis) constitute the majority of these migrations. On the other hand, since Iran has an important position in the transition to the West, it constitutes an important pillar of human migration. In this respect, the consequences of immigration on border security in Iran are much more important. For this reason, the Iranian administration focuses more on the problem of illegal immigrants. Illegal migration has various positive and negative effects in Iranian cities and political areas in terms of economic, administrative, administrative and sociological aspects. It puts great pressure on regional integrity, welfare and social development, compliance with human rights and international standards, national health and safety, the development of international cooperation, and especially security, and requires enormous costs to control borders. In the last hundred years, population movements in Iran have had a significant impact on the increase in migration flows into the country. Today, economic, educational and social factors in Iran are seen as the main factors that create migration from countries neighboring 
Iran. Due to the active role of migration in the redistribution and effect of the population in Iran, different social, economic and cultural parameters of different regions of the country include the main components of migration in population studies.

According to the results of the 2011 population and housing census, according to the results obtained from spatial dimensions, distribution and spatial preference reasons, Alborz, Tehran, Isfahan and Gilan and Khuzestan, Kermanshah and Marat, Larsat, Marat and Lars are the most sought after by immigrants and the most influx of immigrants. It stands out as the Iranian cities where it is located (Mahmoudi, Mushfeq and Kazemipour, 2012). According to the results of the 2011 population and housing census, according to the results obtained from spatial dimensions, distribution and spatial preference reasons, Alborz, Tehran, Isfahan and Gilan and Khuzestan, Kermanshah and Marat, Larsat, Marat and Lars are the most sought after by immigrants and the most influx of immigrants. It stands out as the Iranian cities where it is located (Mahmoudi, Mushfeq and Kazemipour, 2012).

According to the 2011 census, a total of three million people immigrating to the country is equivalent to $56 \%$ of the intraprovincial migration, this rate is equivalent to $1.8 \%$ of the immigrants imported from Turkey (especially after the Iran-Iraq war there was a wave of migration from Turkey). (Ardhaei, Hosseini, 2013). About $50 \%$ of the migrations within the country are based on familial migrations.

Among the causes of internal migration in studies on internal migration; The share of education stands out as the most important factors with $13.2 \%$ and $7.6 \%$ of access to suitable housing (Iran Statistics Center, 1996). Network migration is a form of the gradual spatial displacement of groups of people between two relatively distant geographic regions due to the existence and expansion of relationships between members and families of potential immigrants with relatives. The socioeconomic characteristics of the immigrants are very effective in ensuring the network migration from East Azerbaijan to Tehran. The weaker the immigrants are compared to their counterparts, the more they tend towards network migration. Illiterate people with basic education and in the movement, unemployed, farmer, single, and those with low to moderate financial status are more likely to apply for network migration (Khomeini, 2013; Haj Hosseini, 2006).In the land management plan, which is related to the management and planning of population density and distribution, Iran benefits from network migration in preparing the ground for attracting influential people who can play a leading role and directing the network to sparsely populated areas by taking the necessary precautions (Ardakani, 1985).
The share of immigrants entering Tehran is still the highest, but its share declined from $28.4 \%$ in 1999 to $19.8 \%$ in 2009.The desire to immigrate to Tehran declined in 2009. However, immigration to Gilan province is increasing. The number of immigrant provinces increased from 15 in 1996 to 16 in 2017 (Iran Statistics Center, 2006; 2011; 2018).

In Turkey, when we classify the history of migration as internal and external, the basis of internal migration is mostly the break from economic, education, security and agricultural areas. It is understood from the laws enacted that external migrations were based on the same religion, language and blood ties - at least until 2011, this was the case. Until the last ten years, Turkey has faced more internal migration. In this respect, it would not be wrong to say that the country has not entered into an adequate legal regulation on immigration. Demirhan and Aslan state that until 2013, it is impossible to talk about the existence of the institutional structures that Turkey has fallen upon in the management of migration in the field of migration. In addition, it is stated that until 2013, there was not a healthy migration management process in Turkey with scattered and insufficient institutionalization in migration (Kara and Dönmez Kara, 2016).

Internal migrations vary depending on the country's economic development, social understanding, political thought, and religious structure. In addition, since internal migration occurs in the form of settlements from rural areas around the city, internal migration movements in the country are in the form of agglomeration. The focus of the capital in a certain area, the weakness of political thought, and the inadequate measures of the city administrations on migration are what triggered this fainting. Therefore, the internal migration movement in the country contributes to disrupting the balanced growth and unhealthy development in urbanization. This situation causes the socioeconomic developments in the country to progress negatively.

Knowing and managing the effects of immigration on countries requires knowing the effects of immigration on cultural, economic, political and religious elements. In this respect, when we look at the urbanization of Turkey, it is necessary to look for the effects of internal migration in the gaps in the city administrations and the change in the understanding of urbanization. Because when we look at the urbanization of Turkey, it is seen that the internal migration in the east-west axis that has been continuing since the 1950s has been deprived of a circular expansion as in Iran. The weakness of the underground wealth has an important role in this. However, the fact that the migration movement was unidirectional and the lack of capital fluidity brought about the concentration of the labor market in certain places, and thus allowed the emergence of a systematic 
migration for the immigrants, although not for the management. In the 1970s, 1980s and 1990s, when the migration became systematic, it is seen that those who migrated to the west established new living areas based on fellow townsmen and carried the culture of the place they came from there. It is striking that those in the political spectrum, which enables these new living spaces to become widespread, approach the issue in the context of vote and power. As a matter of fact, it is known that there are associations and foundations formed by those who migrated to big cities. In this way, it is easier for people coming from a certain region to gather around this association and foundation on the axis of solidarity to transfer their own culture to big cities, and by this means, big cities become more complex and difficult to manage.

The wave of liberalization that started in Turkey since the 1980s showed its effect in a short time and had an impact on internal migration gaining weight in favor of the city. In 1985, the urbanization rate increased by $53.03 \%$, surpassing the rural population rate for the first time. Beginning from this date, the rate of migration to cities has been on a continuous increase. As of 2021, the urbanization rate in Turkey has reached 93\% (TUIK, 2021).If we make a brief summary of the urban-oriented nature of internal migration in Turkey, we see that the quality of education is better in the cities, the capital does not go out of the big cities, the flow of work migration to the big cities, the mechanization of rural areas and the terrorist incidents that started especially since the mid-1980s. Since the 2000s, due to the fact that foreign capital has preferred certain places due to globalization, internal migration events have continued to occur around the centers of important big cities.

The phenomenon of migration in Turkey, like Iran, contains tensions within itself. Although it is seen that the Turkish nobility is at the center of these tensions, since 2011, Turkey has become a country that receives mass immigration as a result of the war in Syria. Faced with a migration flow based on Turkish nobility from the foundation of the Republic to the end of the 1990s, Turkey has the provisions included in the Settlement Law No. 2510 dated 1934.Therefore, the country's understanding of external migration was generally based on "blood ties" until 2011.

It is possible to examine the external migrations to Turkey under three headings. The first is the migrations from the Balkans, which started with the First World War, and were formed by the Turkish nobility. In the Settlement Law No. 2510 dated 1934, it is stated in the law that those who will immigrate to Turkey are only for Turkish nobles. The second is the 1950s, which started when Turkey signed the Geneva Convention and became a member of NATO. With this agreement, Turkey stated that it would respond to the refugee demands from the member states of the Council of Europe and limited its migration policies in terms of security. The last one covers the migration movements from the Balkans (the share of conflicts is large) that took place in the 1990s (Örselli and Babahanoğlu, 2016). It is seen that the general weight of the external migrations to Turkey is from the countries of the same religion and region. In this context, Turkey's first mass exodus of oil was in 2011.Starting from these years, the problems in the placement and distribution of immigrants fleeing the war in Syria within the country where they came to Turkey in the first period also shows the inadequacy of Turkey in migration management.

It is understood from the studies that the preferences of immigrants coming to Turkey to come to the country are economic, religious, proximity to the region they migrated to and security-oriented. In a study conducted in Zonguldak in 2016, mostly Iraqis, the participants stated security as the reason for leaving their country at a rate of $82.2 \%$. Security-related reasons were followed by political reasons with $7.3 \%$, economic reasons with $6 \%$, and religious reasons/sect with a rate of $2.8 \%$. The reason why the participants chose Turkey is that Turkey is close to the region by $42.5 \%$ and living conditions are better at a rate of $26.3 \%$. Turkey's election rate for religious reasons is $6.9 \%$ (Sankir et al., 2016). Migration needs to be managed in order to ensure that migration movements function properly and to prevent problems for states and societies. Otherwise, it is inevitable that unrest will arise between the irregular arrivals and the societies of the countries they go to. With the world turning into an age of migration (Castles and Miller, 2008), the question of how to overcome the management crisis is also sought for an answer.

\section{Migration Management in Iran and Turkey}

It is important for the states to control the migration movements regularly, to register the arrivals and to direct them through the necessary institutions. Because, in which periods and how incoming migration movements were made, the depth of cultural differences, the relations of the immigrants with the residents are related to helping the states, especially nation-states, to overcome the problems that they will fall into. For this reason, there are certain elements for the management of migration (Altunok, 2017). First, there is the issue that immigration has become permanent. While the social tensions remained at a minimum level due to the fact that Turkey's previous out-migrations mostly had the same language, religion and culture, serious problems arising from the migrations from Syria show that Turkey's migrations will become permanent. On the other hand, it is important that the migration movements in Iran are permanent in 
terms of Afghans and Pakistanis. After the occupation of Afghanistan by the former Soviet Union and the start of the civil wars, large numbers of Afghan refugees flocked to the Islamic Republic of Iran. Khorasan provided aid and accommodation for 300,000 Afghans between 1980 and 2001.An organization called the Afghan Affairs Coordination Council was established under the Khorasan governorate to manage these immigrants. It continues in coordination with the Governor's Office and the Ministry of Internal Affairs, General Directorate of Citizen Affairs.

The second element is that immigration has now become a public phenomenon for states and governments. Accordingly, border security in migration is supported by public power. Third, it is thought that there is a need for a separate expertise in the public bureaucracy in terms of the language of legislation and international nature of the countries. Issues such as the conditions under which immigrations to stable and economically developed or developing countries will be accepted or rejected, and to what extent cultural hybridity will be accepted, are proportional to the bureaucratic functioning of the legislation. Fourth, countries now support the idea that immigration should be approached with a focus on internal and external security and that states should establish the necessary security to maintain their existence. The rate of involvement in crime of immigrants coming to the country and attempts to establish a criminal organization due to the formation of a new super-ego are evaluated within this element. The fifth element is the idea that the policies to be produced in the field of migration are directly linked to other fields in facilitating and coordinating migration management by countries. Therefore, the control of migration within the central and local administrations requires an effective organization.

Migration management starts with various practices and legal regulations before immigrants enter a country. Then, meeting the basic needs of the newly arrived human communities after migration and ensuring their integration with the existing society are also evaluated within the scope of migration management (Kabakuşak, 2014).Therefore, migration management describes the process consisting of a national system with stakeholders, including public institutions, which institutionalize the regular and coordinated management of those coming from across the country in accordance with the internal structure of the country (Aktel and Kaygisiz, 2018).

Since migration management requires coordinated measures in terms of border control, transparency, asylum legislation and work permits for foreigners, clarification of legal immigration regulations, strengthening and control of borders, implementation of penal policy in combating migrant traffickers and international cooperation is given due attention in Iran. It requires national and international cooperation to take certain measures in each of them. Comprehensive evaluations are made on migration, especially with the countries of the region. However, it is known that those who enter the country illegally in Iran cannot be fully controlled. In addition, factors such as economic, judicial, cultural, educational and political justice increasingly affect the level of interaction in many different areas such as class conflict, occupation in urban areas, education level and practice, freedom of thought and expression, cultural, artistic and sports programs (Bozan, 2007). 2017; Foreign Citizens Affairs, 2001).

According to Georgi (2010), migration management aims to achieve four main goals: Maximizing the economic growth potential of migration Facilitating the legal migration of tourists, students and legal labor migrants, combating unwanted and illegal migration and controlling forced migration, helping refugees and displaced persons. In order to control regular and irregular migration in Iran and to ensure its coordination within the country, the Presidency, the Ministry of Foreign Affairs, the Ministry of Interior and its affiliated Foreigners and Foreign Immigration Affairs Bureau (BAFIA works in coordination with the United Nations) and the Foreign Nationals Organization Commission, Provincial Foreign Citizen Organization Commission They cooperate with the Governorship of Khorasan, where Afghans live heavily and become permanent, and with the governorships of other cities where immigrants are concentrated, in the management of migration. In this context, some of the duties undertaken by BAFIA, which was established in 1980, are as follows: To implement the necessary policy and coordination with relevant institutions and organizations to prevent the uncontrolled entry and exit of foreign nationals and immigrants; Supervising, controlling and conducting the legal affairs of foreign nationals, including marriage, citizenship, acquisition, dispute resolution, employment; To supervise and follow the works and cultural activities of the political organizations of foreign nationals; Issuing or renewing the identity documents and movements of refugees and examining their residence documents, compiling files, registering and creating database and statistics; To organize them in order to prevent social security and legal consequences due to their presence in cities (Third Development Plan Law, Refugee Provisions Art. 48);In order to serve the refugees, it cooperates on certain issues such as interacting and cooperating with international organizations to attract international facilities and funds, especially in the United Nations High Commissioner for Refugees, other foreign organizations and non-governmental organizations and international charities (Foreigners and Foreign Immigrants) (Bureau, 2021, http://www.tehranatba.ir/). A new agency established in 2018 under BAFIA is the "National Immigration 
Organization". The reason for the establishment of this organization has been expressed as focusing on the affairs of foreign nationals, immigrants and refugees, as well as policy making, managing, planning, monitoring, organizing and communicating effectively with international institutions and organizations. While performing the duties and powers of the Organization and the duties of the executive organs, the forms of cooperation are determined by law. The organization is organized at the central general directorate level. Provincial and district duties are carried out by governorships. The Ministry of Interior is preparing the draft on the establishment of the said organization together with the mission of the organization together with the Administration and Employment Organization in the country and other institutions related to the affairs of foreign nationals (Ansari, 2018). National Immigration Service; The representative office consists of the Regulatory Commission, Care Camps, Financial Management, Socio-political Management, Administrative Affairs Office and Illegal Immigrants Management office. The duties of some of these offices are as follows. Socio-Political Management is in the most important position. Among the duties of this office; Providing legal and social services to Iranian citizens and foreign nationals such as marriage registration, citizenship and acquisition; Collaborating with international organizations dealing with refugee issues to obtain funding and financial assistance; To follow the needs of immigrants in various fields such as education, technical and vocational, welfare, health and literacy; inspecting cultural centers and organizations of operating Afghan parties and aid organizations; To submit performance and reports on the activities of the General Directorate of Citizenship Affairs to the relevant authorities; Meeting with the participation of representatives of international institutions and officials of official institutions related to the return of foreign nationals to their countries, Organizing seminars and conferences. Among the duties of the illegal immigration management office are; Carrying out and supervising administrative affairs related to illegal foreign nationals; To follow up on matters related to the return of illegal citizens to their country of origin; To coordinate with the provincial police directorate on arrest plans (illegal immigrants); There is monitoring of employment of foreign nationals. With the increase in migration movements in the international arena, it has brought important effects on the states in the management of migration. These effects include education, language, religion, culture, security, unemployment, and different lifestyles. Refugee influxes in Turkey, especially in the post-2011 period, necessitated studies on migration and migration management. In this respect, it can be said that a more systematic migration management has been adopted in Turkey since 2013. After the General Directorate of Migration Management (General Directorate of Migration Management) was established in 2013 with the law numbered 6458, migration affairs were transferred to this unit and organized by this unit in 81 provinces of Turkey. The main duties and powers of the General Directorate are listed in Article 104 of the relevant law. Some of those; Developing business and processes to achieve compliance processes; To identify stateless persons in Turkey and to carry out business and transactions related to these persons; To establish combat activities against irregular migration and to ensure the necessary coordination by both law enforcement units and relevant public institutions and organizations; To take existing measures by establishing migration managements (Örselli and Babahanoğlu, 2016). On the other hand, it is necessary to look at the Migration Policies Board, which was established in 2013 with Law No. 6458 in migration management within the General Directorate of Migration Management. The Board, which includes high-level representatives of the bureaucracy, also includes the director of the General Directorate of Migration Management. This committee is chaired by the Minister of Interior. The representatives in the Board are representatives of the Ministries of Family and Social Policies, Foreign Affairs, Interior, Culture and Tourism, National Education, Health, the President of Turks Abroad and Related Communities, and the Director General of Migration Management. When necessary, representatives of relevant ministries, national-international institutions and organizations and non-governmental organizations may be invited to the meetings of the Board. Increasing economic and political power and stable structure in recent years have made Turkey a center of attraction for regular and irregular migration movements. On the other hand, Iran's positive relations with Europe in nuclear agreements, oil agreements with China, and investment commitment of 400 billion dollars to enter the country, provided that it spreads over a 25 -year period with China, make Iran more attractive in terms of immigration. This situation will lead to more cooperation with the countries in the region in dealing with irregular migrations in Iran.In addition, Iran aims to reduce the internal fragility of migration by making the necessary legislative arrangements on irregular migration. However, Iran still has not made any headway on irregular migration. It needs international and regional cooperation in this regard. Because Iran, like Turkey, has problems in harmonizing internal and external migrations. The existence of irregular migrants is still not resolved for both countries. Therefore, some of the irregular migrants choose Turkey as a transit country, while others work as illegal workers and use it as a destination country. This is also true for Iran, and it brings up economic, social, cultural and demographic issues as well as urbanization, public order and security for both countries. Some of the features that Deniz (2014) identified regarding irregular migration towards Turkey are valid for its neighbor Iran. First; Increasing political conflicts and uncertainties in neighboring countries have 
increased the desire of the citizens of these countries to go to a safer, oppression-free and better living conditions. Secondly, Turkey's geographical structure makes the country attractive to transit migrants (Deniz, 2014). Migration is an issue that generally concerns the central governments of countries. However, it is certain that cities and city governments are among the places most affected by migration. The capacities of cities are being challenged and even overflowed with migrations. In this respect, the environment and nature of cities also cause new and uncertain situations and urban crises between residents and immigrants. Turkey, which is on the migration routes due to its geographical structure, is greatly affected by this situation.

Certain places in the districts of some cities began to be remembered by those who fled the Syrian war and came to Turkey. Those who settle here bring their own living spaces and protect their language, belief and family structures and prevent them from disappearing into the settled people. The "areas of occupation" that Chambers refers to are the result of such an event. In Turkey, important problems arise in cities where there are Syrians, where there are trade and job opportunities, and in border cities (Erdoğan, 2018; Ertan and Ertan, 2017). In Iran, some initiatives have been made for immigration, especially in cities.It was aimed to decentralize the cities, especially the big cities that are exposed to more immigration, to prevent the formation of large urban complexes within the city and the capital, and to play an important and effective role in the prevention of rural migration as a result, but due to the indifference of the city administrators, a reverse process was carried out. Today, the important cities of Iran, such as the city of Ilam, face many problems such as suburbanization, haphazard construction in the fabric of the city, lack of stability, inappropriate planning of the municipalities have left the city administrators in a difficult situation and led to the dissatisfaction of the citizens and the instability of the city. It is stated that if a solution to these problems cannot be found, a network of cities affected by the crisis will be encountered in the not too distant future (Ebrahimzadeh and Fatemi, 2014; Irandost and Amini, 2011).

\section{Conclusions}

Migration, by its nature, is a phenomenon that affects not only those who move, but also the lives of residents. This effect seems to be felt more by the states now. It is the effect of increasing mass migration in recent years that provides this visibility. Although these mass migrations are the most affected, they do not only affect countries such as Iran and Turkey, but also regions and the world. Therefore, systematic management of migration requires extensive cooperation. The healthy functioning of this cooperation is primarily possible if the states manage migration management well.

Turkey remained far from a regular migration management until 2013.The reason for this is that Turkey has not met with mass migrations - not counting those of Turkish descent. I in 1991.Migration that started from Iraq after the Gulf War, from Bosnia between 1992-1998, from Macedonia in 2001, and finally from Syria in 2011, forced Turkey to produce a policy on migration management because the numbers of the masses that started to come from Syria exceeded millions. With its establishment in 2013, the issue of immigration resulted in a single handicap.

Due to its geographical and strategic location, Iran, like Turkey, has remained at the center of mass migration as a country that both receives and sends immigrants. Therefore, Iran's institutionalization efforts on migration date back to BAFIA, which was established in 1980. In 2018, it turned to a wider study and implemented the "National Immigration Organization" and gained an active role in the fight against all kinds of migration.

Finally, today Iran and Turkey have made some progress in migration management. The factor of exposure to mass migration has an important place. It is expected that large and intense migration movements towards the cities of the two countries will continue in the coming years. For this reason, it is considered that migration management will be a priority in their foreign policies in the future, as the two countries cooperate both regionally and historically and are transit points.

\section{References}

1. Afrough, E. (1998). Providing a Model for Spatial Separation of Space and Social Inequality and Its Consequences. Tarbiat Modares University. Available at https://elmnet.ir/Article/31118303$\underline{51061}$

2. Akhbari, M. V. and Mohammad H. (2009). Border Geography with Emphasis on Iranian Borders. Tehran: Geographical Organization of the Armed Forces. Available at http://opac.nlai.ir/opacprod/bibliographic/1841857

3. Akhtar, S. (2018). Immigration and Identity Confusion, Healing and Transformation. Istanbul: Sphinx Book. Available at https://dergi.tplondon.com/goc/article/view/653

4. Aktel, M. and Kaygisiz, Ü. (2018). Migration Management in Turkey. Suleyman Demirel University 
5. Ansari, J. (2018). İslami Danişma Meclisi, "Ulusal Göçmenlik Teşkilati" nin kurulmasina ilişkin Yüksek İdari Konsey Karari. No. 76229 1397/2/23. Available at https://rc.majlis.ir/fa/law/show/1059505

6. Ardakani D. R. (1985). Nationalism, National Sovereignty and Independence. Isfahan: Question Publishing. Available at https://www.cgie.org.ir/fa/news/153538

7. Ardha Q. A. and Hosseini R. A. (2013). Currents of Internal Migration in Iran 85 of 1375. Population Quarterly Bulletin. Issue 65. Available at https://www.noormags.ir/view/fa/articlepage/492725 1

8. Aslani, M. (2006). A Study on Immigration Trends in the Islamic Republic of Iran in the Last Three Years and Its Impact on National Security with Importance of Internal Migration to Tehran. Jamiat Quarterly. Available at https://www.noormags.ir/view/fa/articlepage/316927

9. Bozan, B. (2017). İnsanlar, Hükümetler ve Korku. Stratejik Araştirmalar Araştirma Enstitüsü Tercümesi. Tahran: Stratejik Araştirmalar Araştirma Enstitüsü. Available at https://www.gisoom.com/book/1153877

10. Castles, S., Miller, M. J., Bal, B. U., \& Akbulut, I. (2008). The age of migrations: International migration movements in the modern world. Istanbul Bilgi University. Available at https://www.academia.edu/43378380/

11. Chambers, Ian (2014). Migration, Culture, Identity. (trans. İ. Türkmen and M. Beşikçi). Istanbul: Detail. 2nd Edition. Available at http://kutuphane.gam.gov.tr/cgi-bin/koha/opacdetail.pl?biblionumber $=394$

12. Demirhan, Y. and Aslan S. (2015). Turkey's CrossBorder Migration Policies and Management. Journal of Individual and Society. p. 9. p. 23-62. Available at https://dergipark.org.tr/en/pub/birtop/issue/29486/31 $\underline{6343}$

13. Deniz, T. (2014). Turkey in the Perspective of International Migration Issue. TSA Journal. 18(1), 175-204. Available at https://dergipark.org.tr/en/pub/tsadergisi/issue/21491 $\underline{1230375}$

14. Eagleton, T. (2011). Cultural Commentaries. (trans. Ö. Çelik). Istanbul: Detail. 2nd Edition. Available at https://dergipark.org.tr/tr/download/article-file/492

15. Ebrahimzadeh, I. and Fatemi, K. (2014). An Analysis Study on Citizenship Participation and Urban
Governance in Small Cities: Small City of Younesi. Available at

https://www.noormags.ir/view/fa/magazine/number/ $\underline{56198}$

16. Erdogan, B. M. (2018). Social Acceptance and Cohesion of Syrians in Turkey. Istanbul: Istanbul Bilgi University Press. 2nd Edition. Available at https://data2.unher.org/

17. Ertan, K. A. and Ertan, B. (2017). Turkey's Migration Policy. Contemporary Research in Economics and Social Sciences. 1(2), December, pp.7-39. Available at https://dergipark.org.tr/en/pub/conress/issue/35835/4 $\underline{01581}$

18. Foreign Citizens Affairs (2001). NAJA Training Assistant, Tehran, Zonguldak. Available at https://dhttps://www.SID.ir,http://www.tehranatba.ir/

19. Georgi, F. (2010). For the Benefit of Some: The International Organization for Migration and its Global Migration Management. (Editors: Zig Layton-Henry, Danièle Joly). Macmillon England.45-72. Available at https://link.springer.com/chapter/10.1057/978023029 48823

20. Göksel, U. G. (2019). Immigrant Integration and Recognition Theory "Fair Integration”. (trans. M. Kiziltuğ).Istanbul:Pinhan Publications. Available at https://www.sosyalarastirmalar.com/www.sosyalaras tirmalar.com

21. Haj Hosseini, H. (2006). A Look at Migration Theories. Strategy Quarterly. no. 41- Autumn 1785. Available at http://ensani.ir/fa/article/130323

22. Iman, Mohammad T. (1999). Immigration in Third World Countries. Quarterly Journal of Literary Essays. Faculty of Letters and Humanities. Ferdowsi Mashhad University. no. 86 and 87. Autumn and Winter. Available at http://ensani.ir/fa/article/277106

23. Iran Statistics Center (2018). General Population and Housing Census Results. Tehran. Available at https://www.amar.org.ir/

24. Irandost, $\mathrm{K}$ and Amin Amini (2011). Identifying the Challenges of Managing Small Cities from the Perspective of Effective Groups. Urban Studies Quarterly. no. 1. Available at https://urbstudies.uok.ac.ir/article_1276.html

25. Iranian Statistical Center (1996). General Population and Housing Census Results. Tehran. Available at https://www.amar.org.ir/ 
26. Iranian Statistical Center (2006). General Population and Housing Census Results. Tehran. Available at https://www.amar.org.ir/

27. Iranian Statistical Center (2011). General Population and Housing Census Results. Tehran. Available at https://www.amar.org.ir/

28. Irmelo, R. (1984). Migration from Villages to Cities in Iran Chapter 2. Quarterly Journal of Philosophical Studies. Faculty of Letters and Humanities. Tabriz, Issue 133. Autumn. Available at https://www.noormags.ir/view/fa/articlepage/516102 I

29. Kabakusak, D. (2014). Institutionalization of Migration in Turkey in the Framework of Global Migration Governance. Artvin Coruh University Hopa International Social Sciences Conference. Artvin. Available at https://www.academia.edu/10369263

30. Kara, M. and Dönmez Kara, C. Ö. (2018). Migration Governance in Turkey: Institutional Structure and Cooperation. Çanakkale 18 Mart University Journal of Entrepreneurship and Development. 10 (2), 1-25. Available at http://acikerisim.lib.comu.edu.tr:8080/

31. Khomeini, R. (2013). Ethnicity, Nationality and Transnational Thought from Imam Khomeini's Perspective. Tehran: Imam Khomeini Publishing House. Available at http://www.imamkhomeini.ir/fa/c78_79577

32. Lahsaeizadeh, A. (1989). Immigration Theories. Shiraz: Navid Publications. first edition. Available at http://www.lib.ir/book/54403871

33. Mahmoudi, Abdullah (2004); Investigation of the economic causes of brain drain, M.Sc. Thesis, Faculty of Economics and Administrative Sciences, Sistan and Baluchestan University. Available at http://ensani.ir/fa/article/229948

34. Mahmoudi, M. J. Mushfaq, M. Kazemipour, S. (2012). Systematic Analysis of the Position of the Khorasan Region in the Iranian Migration System. Quarterly Journal of Population No. 73. Available at https://www.magiran.com/volume/62838

35. Örselli, E. and Babahanoğlu, V. (2016). Turkey's Migration Management and Development of Migration Policies: A Public Policy Analysis. International Journal of Social Studies. 2016(43), 2063-2072. Available at https://d1wqtxts1xzle7.cloudfront.net/58288218

36. Ozer M. A., and Keskin, O. (2019). Efforts to Create a Subculture on Migration and Migration in Turkey: Ankara Metropolitan Example KAYFOR 2019. 970-
985, Karaman. Available at

https://books.google.com.tr/books?hl=tr\&lr=\&id=cD P3DwAAQBAJ\&oi=fnd \&pg $=$ PP1\&dq=\%C3\%96zer $\underline{+ \text { M.+A+ve+Keskin+O.+(2019) }}$

37. Sankir, H. Sankir S. et al., (2016). Refugees in Zonguldak: Life Experiences, Problems and Suggestions. Bulent Ecevit University Publications No:09. Zonguldak. Available at https://www.academia.edu/24557474

38. TUIK. (2020). Adrese Dayalı Nüfus Kayıt Sistemi Sonuçları. (Address Based Population Registration System Results). Nüfus ve Vatandaşlık İşleri Genel Müdürlüğü. Available at https://data.tuik.gov.tr/Bulten/Index?p=AdreseDayali-Nufus-Kayit-Sistemi-Sonuclari-2020-37210 20.04.2021

39. Yabancilar ve Yabanci Göçmenler Bürosu. (2021). Available at http://www.tehranatba.ir/ 05.05.2021

40. Yükseker, D. (2018). Approaches to Migration in Social Sciences: The Case of Turkey, Psychoanalysis and Migration to Go or Stay? (ed. N. K. Bilen). Istanbul: İthaki, pp.242-253. Available at https://dergipark.org.tr/tr/download/issue-fullfile/58765 